\title{
Host status of passion fruit genotypes to scab and bacterial blight
}

\section{Hospedabilidade de genótipos de maracujazeiro a verrugose e bacteriose}

\author{
Roxana Stefane Mendes Nascimento ${ }^{1 *}$; Everaldo Antonio Lopes ${ }^{2}$; \\ Viviane Manuela Bernardes Silva Magalhães 3 ; José Avelino Cardoso ${ }^{4}$; \\ Carlos Eduardo Magalhães dos Santos ${ }^{5}$; Rafael Oliveira Antunes ${ }^{1}$
}

\begin{abstract}
Screening passion fruit genotypes to target resistance to scab and bacterial blight may play an important role in reducing the application of chemical products and decreasing losses caused by these diseases. It is likely that resistant genotypes can be found in ongoing breeding programs targeting production traits. Thus, the objective of this work was to evaluate the host status of eighteen passion fruit genotypes from the Breeding Program of the Universidade Federal de Viçosa (CRP 01-12 to CRP 16-12, CRP 19-12 and CRP 20-12) and two cultivars (FB 200 Yellow Master and FB 300 Araguari) of yellow passion fruit to scab (Cladosporium herbarum) and bacterial blight (Xanthomonas axonopodis pv. passiflorae). The fungus and the bacterium were artificially inoculated on wounded leaves at concentrations of $1 \times 10^{6}$ spores $\mathrm{mL}^{-1}$ and $1 \times 10^{8} \mathrm{cfu} \mathrm{mL}^{-1}$. Scab incidence and severity were assessed at 7, 14, 21, and 31 days after inoculation (DAI); whereas bacterial blight evaluations were performed at 10, 20, 28, and 44 DAI. The genotypes CRP 01-12 to CRP 16-12 and CRP 19-12 are moderately resistant to scab. All genotypes are highly susceptible to bacterial blight.
\end{abstract}

Key words: Bacterial spot. Cladosporiosis. Passiflora edulis. Resistance.

\section{Resumo}

A seleção de genótipos de maracujazeiro visando resistência à verrugose e bacteriose pode ter importante papel na redução da aplicação de produtos químicos e perdas causadas por essas doenças. É provável que genótipos resistentes possam ser encontrados em programas de melhoramento visando seleção de caracteres relacionados à produção. Assim, o objetivo deste trabalho foi avaliar a hospedabilidade de dezoito genótipos de maracujazeiro-azedo provenientes do Programa de Melhoramento Genético da Universidade Federal de Viçosa (CRP 01-12 a CRP 16-12, CRP 19-12 e CRP 20-12) e dois cultivares comerciais (FB 200 Yellow Master e FB 300 Araguari) à verrugose (causada por Cladosporium herbarum) e bacteriose (Xanthomonas axonopodis pv. passiflorae). O fungo e a bactéria foram inoculados em folhas com ferimentos nas concentrações de $1 \times 10^{6}$ esporos $\mathrm{mL}^{-1}$ e $1 \times 10^{8} \mathrm{ufc} \mathrm{mL}^{-1}$. A incidência e a severidade de verrugose foram avaliadas aos 7, 14, 21 e 31 dias após a inoculação (DAI); enquanto que as avaliações da bacteriose foram aos 10, 20, 28 e 44 DAI. Os genótipos CRP 01-12 a CRP 16-12 e CRP 19-12 são moderamente resistentes à verrugose. Todos os genótipos são altamente suscetíveis à bacteriose.

Palavras-chave: Mancha bacteriana. Cladosporiose. Passiflora edulis. Resistência.

\footnotetext{
${ }^{1}$ Discentes, Pós-Graduação em Produção Vegetal, Universidade Federal de Viçosa, Campus Rio Paranaíba, UFV, Rio Paranaíba, MG, Brasil.E-mail: roxana.mendes@hotmail.com; roaagronomia@yahoo.com.br

2 Prof., Pós-Graduação em Produção Vegetal, Campus Rio Paranaíba, UFV, Rio Paranaíba, MG, Brasil. E-mail: everaldolopes@, ufv.br

${ }^{3}$ Discente em Agronomia, Campus Rio Paranaíba, UFV, Rio Paranaíba, MG, Brasil. E-mail: viviane.manuela@ufv.br

${ }^{4}$ Prof., Instituto Federal de Educação, Ciência e Tecnologia do Tocantins, Campus Dianópolis, Dianópolis, TO, Brasil. E-mail: j.avelino86@hotmail.com

5 Prof., Pós-Graduação em Fitotecnia, UFV, Viçosa, MG, Brasil. E-mail: carlos.magalhaes@ufv.br

* Author for correspondence
} 
Brazil is the world's largest producer of yellow passion fruit (Passiflora edulis Sims), with an estimated output of 838,244 tons and a planted area of 58,089 hectares per year (IBGE, 2013). Passion fruit can be cultivated throughout Brazil, but diseases limit crop production in some regions.

Scab, caused by the fungus Cladosporium herbarum, and bacterial blight, caused by the bacterium Xanthomonas axonopodis pv. passiflorae, are two of the most serious passion fruit diseases in Brazil. Premature plant death, defoliation, and delayed ripening are some of the symptoms caused by these diseases, which reduce both fruit production and quality. These pathogens infect all commercially grown passion fruit species and are widespread in all production areas (OLIVEIRA et al., 2013).

Screening passion fruit genotypes to target resistance to scab and bacterial blight may play an important role in reducing the application of chemical products and decreasing yield losses. Cultivars are often crossed with wild species for introgression of resistance genes into the desired genotypes. Few disease-resistant passion fruit cultivars, however, are available to Brazilian producers (FLORES et al., 2012; VIANA et al., 2014). Constant efforts are therefore needed to develop cultivars resistant to major diseases of the crop, such as scab and bacterial blight. It is likely that resistant genotypes may be found in ongoing breeding programs targeting production traits. Thus, the objective of this work was to evaluate the host status of eighteen passion fruit genotypes from the Breeding Program of the Universidade Federal de Viçosa (UFV), Brazil, to scab and bacterial blight.

The eighteen passion fruit genotypes (CRP 0112 to CRP 16-12, CRP 19-12, and CRP 20-12) were selected from the Breeding Program of the Universidade Federal de Viçosa (UFV), based on fruit production and quality. The materials were recombined and selected among and within half-sib families. Cultivars FB 200 Yellow Master and FB
300 Araguari were included in this work because they are widely used in Brazil. The experiments were carried out in a greenhouse with average maximum and minimum temperatures of 36 and $18.5^{\circ} \mathrm{C}$, respectively; average relative humidity was $67.2 \%$.

Seeds were sown in plastic bags $(10 \mathrm{~cm}$ diameter by $22 \mathrm{~cm}$ height) filled with an organo-mineral substrate (Plantmax ${ }^{\circledR}$, Eucatex Agro, Paulínia, SP, Brazil). After germination, plants were thinned, with one remaining seedling per plastic bag. Plants were transferred to 2-L plastic pots filled with autoclaved $\left(120^{\circ} \mathrm{C}\right.$ for $\left.2 \mathrm{~h}\right)$ substrate soil: sand $(1: 1, \mathrm{v}: \mathrm{v})$.

The fungus was isolated from infected passion fruit leaves (ALFENAS; MAFIA, 2007), collected from a commercial orchard in Rio Paranaíba, Minas Gerais State, Brazil. To prepare the inoculum, the fungus was grown on PDA for 15 days at $25^{\circ} \mathrm{C}$ in a BOD incubator. Conidia were harvested by adding $5 \mathrm{~mL}$ of sterile distilled water to each dish and scraping the culture surface with a glass rod. The suspension was then filtered through cheesecloth. Conidia concentration was determined using a hemacytometer and a light microscope, adjusted to $1 \times 10^{6}$ conidia $\mathrm{mL}^{-1}$.

The plants were inoculated at the 6-leaf stage by spraying about $10 \mathrm{~mL}$ of the conidia suspension on the adaxial leaf surface. Two leaves from the central portion of the plants were previously wounded with a sterile needle, and the wounded site covered half of the leaf lamina. Distilled water was applied on the plants as control treatment. After inoculation, plants were kept in a moist chamber (about $100 \%$ humidity) for $72 \mathrm{~h}$ at $26 \pm 2{ }^{\circ} \mathrm{C}$. Plants were then removed from the moist chambers, kept on greenhouse benches, and watered once or twice a day depending on soil moisture conditions, with the leaves remaining dry. Fertilization was performed at 15-day intervals by adding $30 \mathrm{~mL}$ per plant of a commercial water-soluble fertilizer $\left(3 \mathrm{~g} \mathrm{~L}^{-1}, 15-\right.$ 15-20 NPK + Ca, S, Mg, Zn, B, Fe and Mn; Ouro Verde, Assis, Brazil). 
Incidence (number of diseased plants) and severity were assessed at 7, 14, 21 and 31 days after inoculation (DAI). Disease severity per plant was evaluated using a disease index ranging from 1 to 6 (SOUSA, 2009), where 1 = healthy plants; $2=$ lesions only on the leaves; $3=$ lesions on the leaves and stems; 4 = defoliation; 5 = dieback; and $6=$ dead plants. Genotypes were classified as resistant (R) when the average score was $<1.5$; moderate resistant $(\mathrm{MR}-$ score $\geq 1.5$ and $<2.5)$; susceptible ( $\mathrm{S}-$ score $\geq 2.5$ and $<3.5$ ), and highly susceptible (HS - score $\geq 3.5$ ) (SOUSA, 2009). Symptomatic leaves of the genotypes were photographed with a digital camera (Nikon, D3100, 300 dpi resolution). For each plant, maximum severity per leaf was determined using the software QUANT® (VALE et al., 2002). Based on the maximum severity per leaf, the area under the progress curve (AUDPC) was calculated using the polygon method (CAMPBELL; MADDEN, 1990).

Passion fruit leaves with typical disease symptoms were collected from a commercial orchard in Rio Paranaíba, Minas Gerais State, Brazil. In the laboratory, leaves were superficially washed with neutral liquid soap, followed by pathogen isolation on potato dextrose agar (PDA) (ALFENAS; MAFIA, 2007). Bacterial cell concentration was adjusted to $1 \times 10^{8}$ colony forming units (CFU) $\mathrm{mL}^{-}$ ${ }^{1}$, to an optical density of 0.3 (540 nm absorbance) with the aid of a spectrophotometer.

The plants were inoculated at the 10-leaf stage, by spraying about $5 \mathrm{~mL}$ of the bacterial suspension on the adaxial surface of the second, fourth, and sixth leaves. The leaves were previously wounded with a sterile needle and the wounded site covered half of the leaf lamina. Distilled water was applied on the plants as control treatment. After inoculation, plants were kept in a moist chamber (about 100\% humidity) for $48 \mathrm{~h}$ at $30 \pm 2^{\circ} \mathrm{C}$. They were then removed and kept on greenhouse benches. The genotypes were irrigated and fertilized as described above.
Disease was assessed at 10, 20, 28, and 40 DAI. Bacterial blight incidence was evaluated by counting the number of symptomatic leaves per plant. Disease severity per plant was evaluated using a disease index ranging from 0 to 4 (DIAS, 1990), where $0=$ without symptoms; $1=$ up to $25 \%$ symptomatic leaves; $2=25-50 \%$ symptomatic leaves; $3=>50 \%$ symptomatic leaves; $4=$ defoliation (inoculated leaves). Based on the average scores, genotypes were classified as resistant $(\mathrm{R}$ - score 0 ), moderate resistant ( $\mathrm{MR}$ - score 1), moderate susceptible (MS - score 2), susceptible (S - score 3 ), and highly susceptible (HS - score 4) (DIAS, 1990). Symptomatic leaves of the genotypes were photographed. Maximum severity per leaf and the AUPC were determined as described for scab.

Treatments in all experiments were replicated four times; replicates of each treatment were arranged in randomized blocks. Each experimental unit consisted of three pots with one passion fruit plant. Non-inoculated plants were grown as control. All data were tested for normality of the error (Kolmogorov-Smirnov test), homogeneity of variances (Bartlett test), and subjected to analysis of variance $(\mathrm{P}=0.05)$. Means were compared by the Scott-Knott test $(\mathrm{P}=0.05)$, except for disease indexes, which were compared by the Friedman test $(\mathrm{P}=0.05)$.

All inoculated leaves showed typical scab symptoms, regardless of genotype, whereas none of the control plants became diseased until the end of the experiment (data not shown). At 7 DAI, the incidence of diseased plants, the incidence of diseased leaves, the maximum severity per leaf, and the disease index reached $75.0 \%, 16.8 \%, 0.95 \%$, and 1.9 , respectively, with no difference among the genotypes (data not shown). Disease incidence and severity increased until 31 DAI. At this date, the incidence of diseased plants ranged from 81.2 to $100 \%$ (Figure 1A), maximum severity per leaf was $2.56 \%$, and AACPD varied from 14.07 to 51.55 (Figure 1B), with no difference among the genotypes. Average disease index varied from 2.1 
to 2.4 in all genotypes, except in CRP 20-12 and the cultivar FB 200 Yellow Master, which averaged 2.5. All genotypes were therefore classified as moderate resistant (MR), except for FB 200 Yellow Master and CRP 20-12, which were classified as susceptible (SOUSA, 2009).

Figure 1. Incidence of scab (A) caused by Cladosporium herbarum and area under the disease progress (AUDPC) for maximum severity per leaf in eighteen CRP-genotypes and two cultivars (FB 200 Yellow Master and FB 300 Araguari) of passion fruit (Passiflora edulis) at 31 days after inoculation under greenhouse conditions. Ns= No significant difference among cultivars by the $F$ test $(\mathrm{p}=0.05)$. Error bars represent standard deviation $(n=4)$.
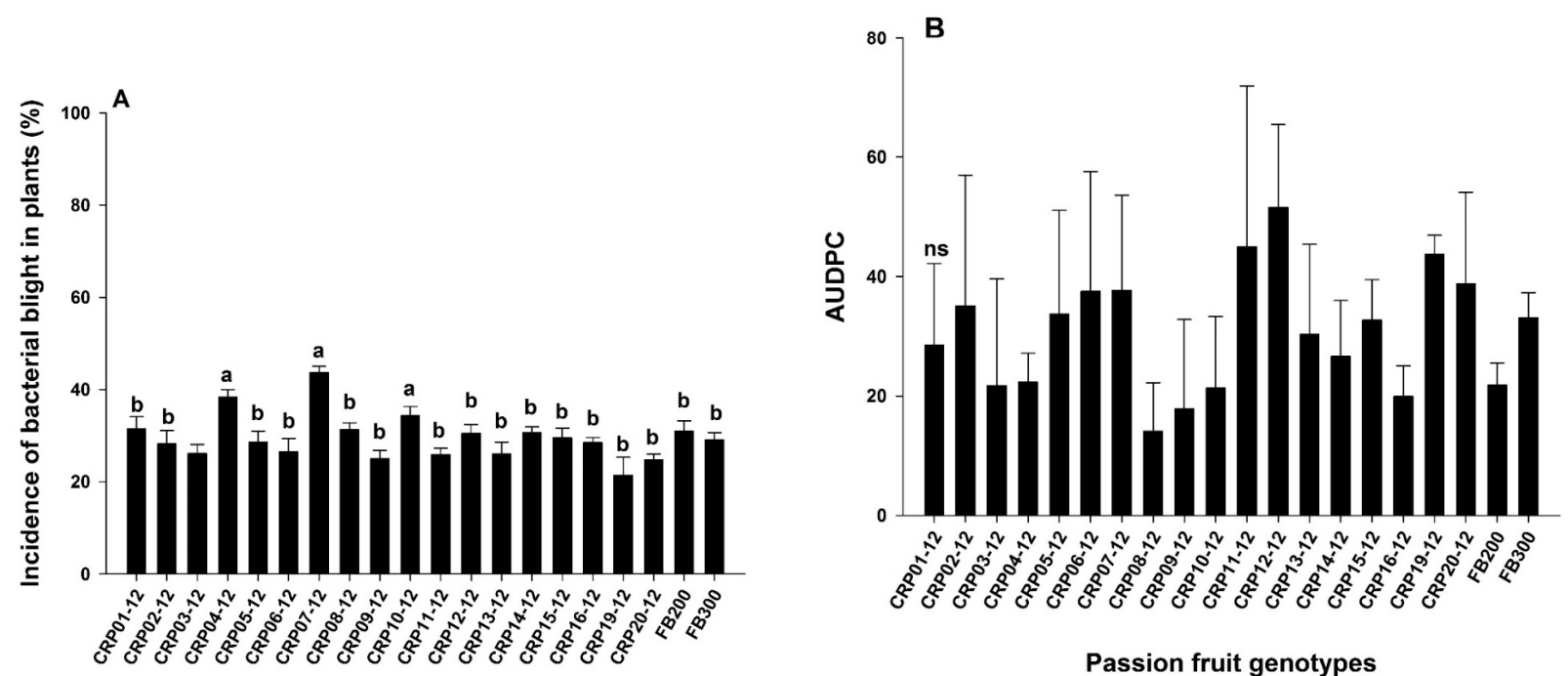

Passion fruit genotypes

Figure 2. Incidence of bacterial blight (A) caused by Xanthomonas axonopodis pv. passiflorae and area under the disease progress (AUDPC) for maximum severity per leaf in eighteen CRP-genotypes and two cultivars (FB 200 Yellow Master and FB 300 Araguari) of passion fruit (Passiflora edulis) at 40 days after inoculation under greenhouse conditions. Means followed by the same letter on the bars do not differ by the Scott-Knott test $(\mathrm{p}=0.05)$. Error bars represent standard deviation $(n=4)$.
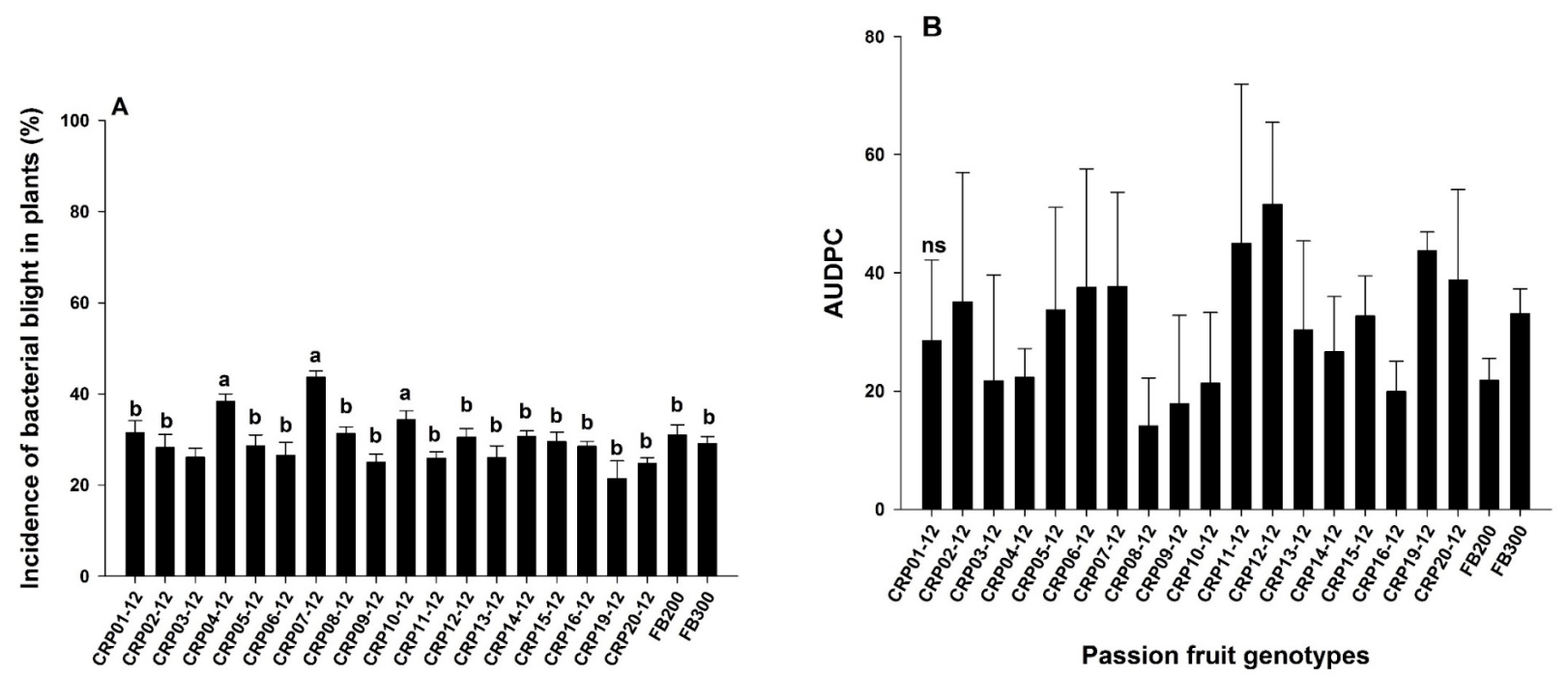
All inoculated leaves showed typical disease symptoms in all genotypes, whereas none of the non-inoculated plants (control) remained healthy until the end of the experiment (data not shown). Bacterial blight symptoms were observed at 20 DAI. The incidence of diseased leaves, severity per plant, and maximum severity per leaf were similar among the genotypes at 20 and 28 DAI. The number of diseased leaves varied from 25.05 to $44.64 \%$, and the maximum severity per leaf varied from 9.33 to $38.96 \%$ (data not shown). The disease severity index varied from score 1 (about 25\%) to score 4 (defoliation).

At 40 DAI, the incidence of diseased plants was higher in the genotypes CRP 04-12, CRP 07-12, and CRP 10-12, varying from 34.32 to $43.72 \%$ (Figure 2A). The maximum severity per leaf was $35.92 \%$. The area under the progress curve (AUDPC) of the disease was lowest in the genotypes CRP 0112, CRP 02-12, CRP 04-12, CRP 06-12, CRP 0712, CRP 08-12, CRP 13-12, and FB 200 Yellow Master (Figure 2B). Defoliation was observed in all genotypes (score 4). Therefore, all genotypes were classified as highly susceptible to bacterial blight (DIAS, 1990).

Seventeen genotypes (CRP 01-12 to CRP 1612, and CRP 19-12) and the FB 300 Araguari cultivar are moderately resistant to scab. Genotypes moderately resistant to scab were also selected in previous studies in Brazil (SOUSA, 2009; COLATTO, 2010), corroborating the potential of finding resistant materials in ongoing breeding programs targeting production traits. The results of the present work may be directed towards the development of resistant passion fruit cultivars with superior yield. Disease-resistant genes can be found in other Passiflora species. Resultant hybrids, however, usually have poor development and are sterile (ZERBINI et al., 2008; FLORES et al., 2012). It is therefore recommended to use the CRP-genotypes and the FB 300 Araguari cultivar in the next selection cycles rather than wild species of Passiflora. Scab-resistant cultivars may reduce losses caused by this disease, increase grower profits, and make passion fruit production more sustainable.

All CRP-genotypes and cultivars assessed in this study are highly susceptible to bacterial blight. Resistance to bacterial blight is not a common trait in passion fruit genotypes. In Brazil, the currently used $P$. edulis cultivars are susceptible to this disease. In some Brazilian studies with objectives similar to those of the present work, the majority of the genotypes were also susceptible to this bacterium (KOSOSKI et al., 2008; SOUSA, 2009; COLATTO, 2010; VIANA et al., 2014).

The eighteen genotypes assessed in this study were selected in the breeding program because of their production traits. Although their apparent disease resistance was also considered during the field steps of breeding, this work showed these genotypes are susceptible to bacterial blight. In addition to the variability among the plant genotypes and the problems with using wild species, the existence of genetic variability among pathogen isolates presents another difficulty for screening of resistant passion fruit genotypes to bacterial blight (NAKATANI et al., 2009; MUNHOZ et al., 2011). Nakatani et al. (2009) studied 50 populations of the bacterium collected from four areas of production in São Paulo State, Brazil, reporting genic flow among the production areas and variability within and among populations of $X$. axonopodis $\mathrm{pv}$. passiflorae. In another study, genetic diversity was also observed by analyzing 87 bacterium isolates collected from 22 fruit orchards in Brazil (MUNHOZ et al., 2011). A single isolate was used in the present study. It is likely, however, that the aggressiveness of this isolate is different from those prevalent in the field at the time of CRP-genotypes selection. Further studies are therefore needed to understand the genetic structure of populations of X. axonopodis pv. passiflorae in Minas Gerais State; this information will be useful for guiding passion fruit breeding programs. 
The genotypes CRP 01-12 to CRP 16-12 and CRP 19-12 are moderately resistant to scab. All genotypes are highly susceptible to bacterial blight.

\section{Acknowledgements}

RSMN thanks CAPES for the scholarship for her Master's degree and EAL thanks CNPq for his Research Productivity Scholarship.

\section{References}

ALFENAS, A. C.; MAFIA, R. G. Métodos em fitopatologia. Viçosa, MG: Editora UFV, 2007. 382 p.

CAMPBELL, C. L.; MADDEN, L. V. Introduction to plant disease epidemiology. New York: John Wiley \& Sons, $1990.532 \mathrm{p}$.

COLATTO, U. L. D. Reação de progênies de maracujazeiro azedo à antracnose (Colletotrichum gloeosporioides), à verrugose (Cladosporium herbarum) e à bacteriose (Xanthomonas axonopodis pv. passiflorae). 2010. Dissertação (Mestrado em Fitopatologia) Universidade de Brasília. Faculdade de Agronomia e Medicina Veterinária, Brasília.

DIAS, S. C. Morte precoce do maracujazeiro amarelo (Passiflora edulis f. flavicarpa) causada por patógenos que afetam a parte aérea da planta. 1990. Dissertação (Mestrado em Fitopatologia) - Universidade de Brasília, Faculdade de Agronomia e Medicina Veterinária, Brasília.

FLORES, P. S.; OTONI, W. C.; DHINGRA, O. D.; DINIZ, S. P. S. S.; SANTOS, T. M.; BRUCKNER, C. H. In vitro selection of yellow passion fruit genotypes for resistance to Fusarium vascular wilt. Plant Cell, Tissue and Organ Culture, Dordrecht, v. 108, n. 1, p. 37-45, 2012.

INSTITUTO BRASILEIRO DE GEOGRAFIA E ESTATÍSTICA - IBGE. Produção agrícola municipal - culturas temporárias e permanentes. Rio de Janeiro: IBGE，2013. Disponível em: <ftp://ftp.ibge.gov.br/ Producao_Agricola/Producao_Agricola_Municipal_ [anual]/2013/pam2013.pdf>. Acesso em: $05^{-}$jun. 2016.
KOSOSKI, R. M.; PEIXOTO, J. R.; JUNQUEIRA, N. T. V.; UESUGI, C. H.; MELO, B. Reação de genótipos de maracujazeiro-azedo a Xanthomonas campestris pv. passiflorae em casa de vegetação. Bioscience Journal, Uberlândia, v. 24, n. 1, p. 60-66, 2008.

MUNHOZ, C. F.; WEISS, B.; HANAI, L. R.; ZUCCHI, M. I.; FUNGARO, M. H. P.; OLIVEIRA, A. L. M.; MONTEIRO-VITORELLO, C. B.; VIEIRA, M. L. C. Genetic diversity and a PCR-based method for Xanthomonas axonopodis detection in passionfruit. Phytopathology, Saint Paul, v. 101, n. 4, p. 416-424, 2011.

NAKATANI, A. K.; LOPES, R.; CAMARGO, L. E. A. Variabilidade genética de Xanthomonas axonopodis pv. passiflorae. Summa Phytopathologica, Botucatu, v. 35, n. 2, p. 116-120, 2009.

OLIVEIRA, E. J.; SOARES, T. L.; BARBOSA, C. J.; SANTOS-FILHO, H. P.; JESUS, O. N. Severidade de doenças em maracujazeiro para identificação de fontes de resistência em condições de campo. Revista Brasileira de Fruticultura, Jaboticabal, v. 35, n. 2, p. 485-492, 2013.

SOUSA, M. A. F. Produtividade e reação de progênies de maracujazeiro azedo a doenças em campo e casa de vegetação. 2009. Tese (Doutorado em Fitopatologia) Universidade de Brasília, Faculdade de Agronomia e Medicina Veterinária, Brasília.

VALE, F. X. R.; FERNANDES FILHO, E. I.; LIBERATO, J. R. Programa Quant - versão 1.0.1. - quantificação de doenças de plantas. Viçosa, MG: UFV, 2002.

VIANA, C. A. S.; PIRES, M. C.; PEIXOTO, J. R.; JUNQUEIRA, N. T. V.; BLUM, L. E. B. Genótipos de maracujazeiro-azedo com resistência a bacteriose. Bioscience Journal, Uberlandia, v. 30, n. 2, p. 591-598, 2014.

ZERBINI, F. M.; OTONI, W. C.; VIEIRA, M. L. C. Transgenic passionfruit. In: CHITTARANJAN, K.; HALL, T. T. (Ed.). A compendium of transgenic crop plants: tropical and subtropical fruits and nuts. Berlin: Wiley, 2008. p. 213-234. 